\title{
História
}

das Ciências

e Educação

\section{A glimpse on a Brazilian pharmacology bibliography of the early-twentieth century*}

\author{
Um olhar sobre uma bibliografia brasileira de farmacologia do início \\ do século XX
}

WEILHER PAULO DOS SANTOS

Universidade Federal de Ouro Preto | UFOP

ANDREA GRABE-GUIMARÃES

Universidade Federal de Ouro Preto | UFOP

\begin{abstract}
The pharmacology books used in teaching have changed considerably since late-nineteenth century. A professor of School of Pharmacy of Ouro Preto, Jovelino Mineiro, conceived the Curso de Pharmacologia (1925-1926), the first of its kind published in Brazil.To demonstrate its historical significance, we compared Mineiro's compendium with Farmacologia, by Penildon Silva (2010), and with the first Brazilian Pharmacopeia (1926). Penildon Silva and Fuchs \& Wannmacher are the most adopted Brazilian authors for teaching nowadays. Concerning the first Brazilian Pharmacopeia, it was possible to observe that Mineiro's work may have been conceived to supply the lack of regulatory guidelines in Brazil at the time.
\end{abstract}

Keywords pharmacology - pharmacy - pharmacopeia - Brazilian authors

RESUMO Os livros de farmacologia utilizados para o ensino mudaram consideravelmente desde o final do século XIX. Um professor da Escola de Farmácia de Ouro Preto, Jovelino Mineiro, concebeu o livro Curso de Farmacologia (1925-1926), o primeiro no Brasil. Para demonstrar a importância histórica, comparamos o compêndio de Mineiro com o livro Farmacologia, de Penildon Silva (2010) e a primeira Farmacopeia Brasileira (1926). Penildon Silva e Fuchs E Wannmacher são os autores brasileiros mais adotados para o ensino de farmacologia. Com relação à primeira Farmacopeia Brasileira, foi possível observar que o trabalho de Mineiro foi concebido para suprir a falta de diretrizes regulatórias no Brasil à época.

Palavras-chave farmacologia-farmácia-farmacopeia-autores brasileiros 


\section{Introduction}

The School of Pharmacy of Ouro Preto was conceived in the Brazilian imperial law number 140 in April 4, 1839, Minas Gerais. It was then a pioneering activity in the autonomous training of pharmacists in Brazil. It emerged due to a necessity to control health care activities in the Province of Minas Gerais, exerted at that time mainly by adventurers and healers. From 1882 on, it became the sole independent School of Pharmacy with a valid diploma throughout the Brazilian territory ${ }^{1}$ ? . Afterwards, in 1969, Federal University of Ouro Preto (UFOP) was created, merging the School of Pharmacy with the School of Mines of Ouro Preto 3.4 . Part of this rich history is presently preserved in the collection of the Museum of Pharmacy of UFOP (Museu da Pharmacia da UFOP, MPh/UFOP), a university museum with a diverse collection encompassing several historical objects and equipments.

The historical bibliographic collection of MPh/UFOP, composed of approximately 10,000 specimens, is well-preserved and includes valuable pieces concerning the history of pharmacology teaching in Brazil. This bibliographic collection is mainly from the nineteenth century and written in French; encompassing areas of biology, chemistry, physics, pharmacology, and medicine. Some of these works were adopted in teaching in late-nineteenth century, including Elementos de Pharmacologia Geral ou Principios Geraes de Materia Medica e de Therapeutica 5 by Bernadino Antonio Gomes (1873); Leçons de Thérapeutique ${ }^{6}$ by A. Gubler, F. Leblanc (Org.) (1880); Traité Élémentaire de Thérapeutique et de Pharmacologie ${ }^{7}$ by A. Rabuteau (1884); Traité de Pharmacologie, de Thérapeutique et de Matière Médicale ${ }^{8}$ by T. Lauder Brunton (1888); Leçons de Thérapeutique ${ }^{9}$ by Georges Hayem (1891). There is also a collection of theses produced by the students of the Natural and Pharmaceutical Sciences bachelor's degree between 1893 and 1901, in addition to works by European travelers and naturalists visiting Brazil, encyclopedias, dictionaries, newspapers, magazines, manuals and catalogs of industry equipment, laboratories, and cabinets.

Professor Jovelino Mineiro (1864-1930) (Figure 1A), born Jovelino Armínio de Souza Mineiro, was a pharmacist and held a bachelor's degree in Natural and Pharmaceutical Sciences. He imparted lectures of Pharmacy and Pharmacology at the School of Pharmacy from 1892 until his death ${ }^{10}, 11,12$, 13. While engaged in teaching at the School of Pharmacy, Mineiro conceived a remarkable bibliographical work of great interest: the book titled Curso de Pharmacologia 14 , 15, 16 ("Pharmacology Course", Figure 1B). The first edition was published in 1911, and the second edition in 1925 and 1926 (in two volumes). It was a compendium of pharmacology lessons encompassing mainly mineral compounds, organic acids and their salts, alkaloids, and glycosides - their preparation, purification, and determination of impurities and falsifications. Such substances were therapeutically used at that time, before great discoveries and advances of pharmacology obtained along the twentieth century. This compendium has a tremendous historical and editorial relevance, since it was written by a School of Pharmacy lecturer in early-twentieth century, a period of scarce Brazilian scientific production in pharmacy and pharmacology field. In addition, considering that Mineiro himself states, in the second edition preface, copies of the first edition were quickly sold out $\frac{17}{}$; it was hypothesized the book may have been adopted as a textbook and/or handbook by Pharmacy and Medicine degree courses at another Brazilian educational institutions besides the School of Pharmacy of Ouro Preto. 
A

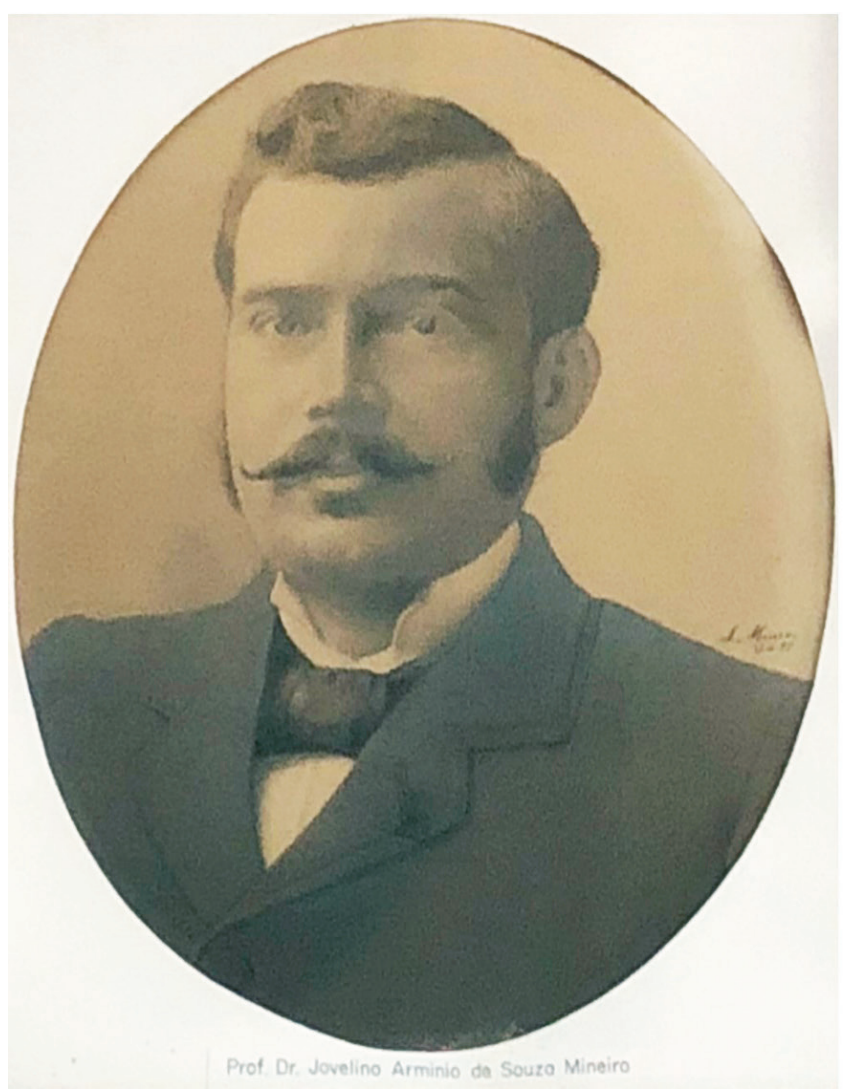

B

\section{CURSO DE PHARMACOLOGIA}

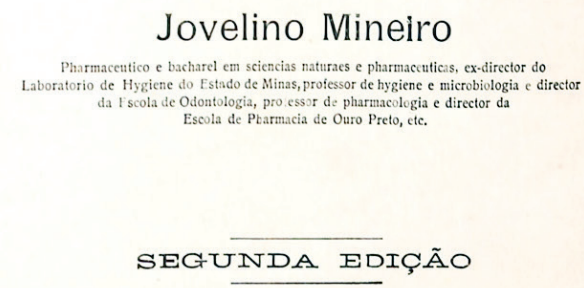

1925

Figure 1: A. Image of a photography of Jovelino Mineiro; B. Inside cover of Curso de Pharmaoclogia (1925) authored by Jovelino Mineiro.

To the best of our knowledge, Mineiro's work is one of the earliest, if not the first, pharmacology textbook written by a Brazilian author using the Portuguese language. According to a rough review contained in José Ribeiro do Valle's manuscript A Farmacologia no Brasil: Antecedentes e Perspectivas ${ }^{18}$ ("Pharmacology in Brazil: Background and Perspectives", 1978), numerous publications addressing therapeutic properties of Brazilian medicinal plants already existed; namely, books describing Brazilian botanical materia medica system, and elements of general and medical botany. However, they did not explicitly bear or employ the term "pharmacology", did not address salts, minerals, and metals used in therapeutics, and were essentially published in foreign languages (mainly Latin and French). Then, our first aim here was to show up the richness of Mineiro's compendium for the twentieth century beginning. Hence, we compared the content of Mineiro's compendium ${ }^{19}, \underline{20}$ with a modern Brazilian pharmacology textbook; namely, Farmacologia ${ }^{21}$ ("Pharmacology") authored by Penildon Silva.

Penildon Silva (1921-2019) retired as a professor emeritus of pharmacology (at Federal University of Bahia - UFBA, and the School of Medicine and Public Health of Bahia), as well as a full professor of the Academy of Medicine of Bahia. He envisioned the publication of a major volume of general pharmacology, first issued in 1980. After almost 40 years and eight editions, this book has grown into one of the most respected Brazilian references in the pharmacology field.

It was also hypothesized that Mineiro attempted to fulfill the lack of Brazilian regulatory guidebooks, such as Pharmacopeias, mainly concerning specific Brazilian plant drugs, by applying a more technical approach to his work. The first Brazilian Pharmacopeia only became mandatory in 192922. 23 . Therefore, in pursuance of an enlightened vision of the possible relation between these manuals, we also undertook a comparison between Mineiro's pharmacology books with a contemporaneous Brazilian Pharmacopeia (1926)는. 
Furthermore, we also considered essential to have a broader awareness of Brazilian authored books used currently in pharmacology teaching. in the light of the considerable change in pharmacology study and teaching, since it was consolidated as science and discipline in late-19 $9^{\text {th }}$ century ${ }^{25}$, we proposed here a historical rescue of contents in pharmacology teaching books in Brazil in the last hundred years. At present, in health degree courses, foreigner pharmacology textbooks are mostly used, particularly U.S. book translations. Despite the existence of great pharmacologists in Brazil's history, including Maurício 0. da Rocha e Silva (1910-1980) and Sérgio Henrique Ferreira (1934-2016), few Brazilian authors have ventured into the organization of a major volume of general or clinical pharmacology, as Mineiro did.

\section{Methods}

\section{Description and comparison of Jovelino Mineiro's Curso de Pharmacologia and a recent Brazilian pharmacology book}

First, the content of Curso de Pharmacologia by Jovelino Mineiro, second edition (1925 and 1926) ${ }^{26,27}$, was analyzed and described in relation to its main characteristics. Then, in order to describe aspects of the evolution of pharmacology books' content in Brazil from the beginning of the twentieth century until the early-twenty-first century, we performed a comparative analysis of Mineiro's book and Farmacologia ${ }^{30}$, edited by Penildon Silva ( $8^{\text {th }}$ Edition, 2010). The first items and contents compared were the preface and index topics. Further, the chapters were analyzed in accordance to the organization of drug groups, pharmacology as science and its subdivisions, such as pharmacodynamics, pharmacokinetics, systemic pharmacology, and therapeutics; including also description of drugs mechanism of action, experimental and clinical effects, adverse effects, and toxicology. Beyond their contents, we also looked into the layout and display of information to students.

\section{Comparison of the first Brazilian Pharmacopeia with Mineiro's pharmacology books}

We performed a comparison between Mineiro's book ${ }^{31}, \frac{32}{2}$ and the first Brazilian Pharmacopeia ${ }^{33}$. The first published Pharmacopeia in Brazil was named Farmacopeia Paulista (Pharmacopeia of São Paulo), organized by João Florentino Meira de Vasconcelos (1866-1919), in 191734. Afterwards, in 1926, the first Brazilian Pharmacopeia, titled Pharmacopeia dos Estados Unidos do Brasi $\underline{35}$ (Pharmacopeia of the United States of Brazil), was approved (decree ${ }^{0} 17.509$ of April

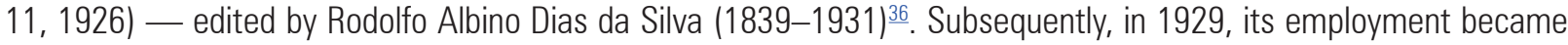
mandatory, and this manual is currently on its $5^{\text {th }}$ Edition (2010) 37 .

\section{Brazilian pharmacology textbooks employed in higher education curricula}

In order to give an overview of Brazilian pharmacology books currently adopted in pharmacology teaching, we scrutinized numerous pharmacology and pharmacology-related discipline current programs. We searched for Brazilian authors into 37 official reference lists of such discipline syllabi on about 30 Brazilian universities and educational institutions. Such syllabi are published in electronic media and are openly accessible. Afterwards, deriving out of those reference lists, we have identified which pharmacology books from Brazilian authors that are currently most widely employed teaching. 


\section{Results and Discussion}

\section{Description and comparison of Jovelino Mineiro's Curso de Pharmacologia and a recent Brazilian pharmacology textbook}

Brazil's scientific history took a huge leap with the arrival of European researchers and naturalists who explored and described Brazilian flora and fauna, back in the nineteenth century ${ }^{38}$. Properties, uses, and toxicity of local medicinal plants were depicted in manuscripts written essentially in Latin, French, and English. Such work continued with the assembly of Brazilian botanists and ethnographers by the imperial government to research unexplored regions of Brazil. Only in the nineteenth century alkaloids begun to be isolated, and therefore defined as plants active component. Thus, the properties of medicinal plants started to become better understood 39 . This sphere of pharmacology would later develop into one of its oldest divisions, pharmacognosy $y^{40}$.

Mineiro's pharmacology book described at least 40 alkaloid properties, extraction and isolation methods, along with mineral compounds, organic salts and acids, and glycosides. Mineiro pioneered compiling a book designed to be adopted as a guide for pharmacy students in pharmacology classes. Curso de Pharmacologia 11 , 2 extensively depicts preparation, purification and identification of drugs and pharmaceutical supplies, essentially compounds derived from plants and other natural sources. There were few synthetic drugs at the time. Indeed, nature's resources - plants, roots, fungi, and animal secretions - were the sole medicine available to treat human diseases until mid-19 $9^{\text {th }}$ century, when pharmaceutical industry begun to emerge. For instance, in 1869, chloral hydrate, a sedative-hypnotic, was the first synthetic drug to be developed. Afterwards, aniline derivatives (such as acetanilide and phenacetin), and acetaminophen (paracetamol, derived from p-nitrophenol) were produced around 1887 (Bayer Company ${ }^{\mathrm{TM}}$, Germany), and became the first synthetic analgesics. Acetylsalicylic acid (Aspirin ${ }^{\circledR}$ ) came later in 1899, also by Bayer ${ }^{\mathrm{TM}}$, and grew into the best-known synthetic drug of all time. Further, the barbiturates, derived from barbituric acid, came in place in the 1900s. For instance, phenobarbital emerged in 1909 and is still useful today (Gardenal ${ }^{\circledR}$, Sanofi-Aventis $\left.{ }^{\mathrm{TM}}\right)^{43}$. Some examples of pages from Curso de Pharmacologia are showed as supplementary material.

Surprisingly, despite the many years separating Mineiro's and Penildon's works, they provide similar definitions of pharmacology. For them, pharmacology is described as the science that studies drugs, or description of drugs interaction with living organisms, assisted by the basic sciences (physics, chemistry, biology, and physiology). Moreover, another aspect worth highlighting is that Penildon's book was intended to be adopted by all health area students, in contrast with Mineiro, who addressed his work only to pharmacy students.

Mineiro states that pharmacology is divided into six components, namely, pharmacography, also called medical material and pharmacogenesis, and studies the description of drugs supplied by the three kingdoms of nature, pharmacodynamics; pharmacotherapy; galenic pharmacy; clinical pharmacy, and therapeutics. On the other hand, according to Penildon, present-day pharmacology can be divided into several branches, namely, general pharmacology, applied pharmacology, pharmacy, pharmacognosy, pharmacokinetics, pharmacotherapy, experimental pharmacology, clinical pharmacology, and toxicology. Clearly, scientific and technological progress has allowed enormous advancements in pharmacology, and consequently the emergence of new areas. For instance, there was an incommensurable progress of pharmacodynamics, revealing drugs mechanism of action, deeply into cellular and molecular aspects. Pharmacokinetics became a solid section of pharmacology in the 1970s, providing crucial tools for pharmacotherapy and clinical pharmacy ${ }^{44}$.

Moreover, the International Union of Basic and Clinical Pharmacology (IUPHAR), a non-profit association of pharmacology societies representing the interests of pharmacologists worldwide, was created in 1959, became independent in 1965, defining since then, the divisions and nomenclature of all pharmacology-related subjects ${ }^{45}$. The Brazilian Society of Pharmacology and Experimental Therapeutics (Sociedade Brasileira de Farmacologia e Terapêutica Experimental, SBFTE), was created soon after, in 1966, affiliated to IUPHAR, and it is since then, responsible for the improvement of pharmacology in Brazil, including researches related to pharmaceutical sciences ${ }^{46}$. 
Preparation, purification, and identification of drugs and pharmaceutical supplies, mainly compounds derived from plants and other natural sources, were extensively described by Mineiro, referred by him as galenic pharmacy, but are no longer within the scope of modern pharmacology. Drug quality control and pharmaceutics are examples of modern areas responsible for such concerns, relatively independent of pharmacology. The aforementioned subjects are prone to be described in guidebooks such as Pharmacopeias, instead of pharmacology textbooks.

Mineiro displayed the categorization of drugs used at the time, based essentially on their therapeutic action, employed by renowned professors and researchers. For example, Henri Soulier (1834-1921), classified the drugs based on the principle of "subordination of its therapeutic effects"; Germain Sée (1818-1896) organized the drugs based on their "internal mechanism" into four groups with distinct subdivisions. Rabuteau and the pathologist Berlioz, for instance, classified the drugs based on their therapeutic action in several groups and subgroups. Finally, P. Carré also divided the therapeutic agents into other numerous groups. The approach of classifying drugs based on their therapeutic action or "internal mechanism" precedes the great discoveries and detailed descriptions of their mechanisms of action, evidencing the scarce resources of pharmacology research at the time. The complete description used by Mineiro of these foreigner researchers are presented in the supplementary material. However, the introduction of systematic pharmacology throughout the twentieth century did not extinguish this method of classifying the therapeutic arsenal in modern pharmacology books. Penildon hence provided a section named systemic pharmacology, where drugs are described according to which biological system they act, and the respective diseases they are meant to alleviate; namely, central and autonomic nervous system pharmacology, cardiovascular pharmacology, respiratory and endocrine system pharmacology, among others.

The development of pharmaceutical industry, along the twentieth century, supplied abundant small organic molecules, supposed to be more selective and effective, in contrast with plant extracts and their galenic preparations, such as syrups, medicinal wines, and elixirs. Therefore, pharmacology gained substantial complexity, requiring a profuse commitment to all basic and health applied areas such as human physiology, pathology, biochemistry, molecular biology and genetics 47,48 .

Concerns regarding drug safety in healthcare are not so recent, being reported since the 1950 s and 1960 s. However, the subject only gained full awareness in the 1990s, with multiple announcements of patients jeopardized, and even killed, by oversights in healthcare ${ }^{49}$. Accordingly, Penildon's Farmacologia ${ }^{50}$ comprises patient safety on sections such as medical prescription, clinical trials, drug-drug interaction, drug toxicology, drugs in pregnancy, and clinical pharmacology. Furthermore, Penildon depicts adverse effects and toxicology of each drug individually in systemic pharmacology section chapters; such information is gathered on pre-clinical and clinical trials, and post-commercialization studies. Conversely, Mineiro's Curso de Pharmacologia provides an abridged depiction of drug adverse effects and toxicology. In the latter, drug properties, and therefore its toxicology, were based on empirical use only; and governed by Paracelsus aphorism "the dose makes the poison". However, today, such statement may be considered an oversimplification, and a jargon used in toxicology ${ }^{51,52}$. Alkaloid compounds, namely, strychnine, cinchonine, morphine, aconitine, heroin, brucine, veratridine, coniine, cocaine, narceine, hydrastine, and colchicine; were heavily used in early-twentieth century, based on their known therapeutic properties. However, nowadays, the development of new drugs associated with evolution in patient safety concern, and their utmost toxicity, have restricted alkaloid use in clinical practice. The evolution of science has allowed the achievement of a better understanding of substances interaction (i.e. xenobiotics) with the living organism. The aspects analyzed in this comparison are further detailed in Tables $1 \mathrm{~A}$ and $\mathrm{B}$.

At first glance, the comparison between Mineiro's compendium $\underline{53}, \underline{54}$ and the textbook Farmacologia ${ }^{\frac{55}{5}}$ may seem unfair - with 100 years of difference. However, when taking into account the context and limitations of pharmacology at the time (1926), Mineiro's compendium can be regarded as an authentic pharmacology book. 
Table 1A: Comparison of Mineiro's Curso de Pharmacologia $(1925,1926)$ with Penildon Silva's Farmacologia (2010)

\begin{tabular}{|c|c|c|}
\hline Aspects & Curso de Pharmacologia & Farmacologia \\
\hline \multirow{4}{*}{$\begin{array}{l}\text { Preface and } \\
\text { index topics }\end{array}$} & Intended for pharmacy students. & Intended for health care students in general. \\
\hline & Alphabetic index only (at the end). & Summary and alphabetic index. \\
\hline & Introductory topics (preliminary). & Introductory chapter describing the nature of pharmacology (general terms). \\
\hline & Drug by drug description (without formal divisions). & Divided in general pharmacology, systematic pharmacology, and special topics. \\
\hline $\begin{array}{l}\text { Organization } \\
\text { of drug groups }\end{array}$ & $\begin{array}{l}\text { Classification of drugs into groups based on their 'internal } \\
\text { mechanism', or their therapeutic action (for instance, } \\
\text { modifiers of the neuromuscular system, trophic and } \\
\text { dystrophic drugs, and excretory medications). }\end{array}$ & $\begin{array}{l}\text { Division in autonomic nervous system pharmacology, central nervous system } \\
\text { pharmacology, immunopharmacology, pharmacology of blood, renal-cardiovascular } \\
\text { pharmacology, pharmacology of the respiratory system, pharmacology of the } \\
\text { endocrine system, and antibiotics, chemotherapeutics, and animal poisons. }\end{array}$ \\
\hline \multirow{4}{*}{$\begin{array}{l}\text { Pharmacology } \\
\text { as a science } \\
\text { and its } \\
\text { subdivisions }\end{array}$} & \multirow{4}{*}{$\begin{array}{l}\text { Pharmacology defined as science that studies medicines - } \\
\text { subsidized by physical-chemical and natural sciences, } \\
\text { and physiology. } \\
\text { Division of pharmacology in 'pharmacography', PD, } \\
\text { pharmacotherapy, galenic pharmacy, clinical pharmacy, } \\
\text { and therapeutics. }\end{array}$} & $\begin{array}{l}\text { Pharmacology defined as study of interaction of chemicals with living organisms, } \\
\text { with deep roots in the basic sciences. }\end{array}$ \\
\hline & & Division of pharmacology in general pharmacology, applied pharmacology, pharmacy, \\
\hline & & $\begin{array}{l}\text { pharmacognosy, PK, pharmacotherapy, experimental pharmacology, clinical pharma- } \\
\text { cology, and toxicology. }\end{array}$ \\
\hline & & Separate chapters for both PK and PD (general terms). \\
\hline \multirow{2}{*}{$\begin{array}{l}\text { Mechanism of } \\
\text { action of drugs }\end{array}$} & Barely addressed. & Described in details (at cellular and molecular level) along drug groups. \\
\hline & Many unknown. & Regarded as part of drug PD. \\
\hline
\end{tabular}


Table 1B: Comparison of Mineiro's Curso de Pharmacologia $(1925,1926)$ with Penildon Silva's Farmacologia (2010)

\begin{tabular}{|c|c|c|}
\hline Aspects & Curso de Pharmacologia & Farmacologia \\
\hline $\begin{array}{l}\text { Clinical and } \\
\text { experimental } \\
\text { effects }\end{array}$ & $\begin{array}{l}\text { Described as drug properties (applications) } \\
\text { Based on empirical use. }\end{array}$ & $\begin{array}{l}\text { Described in details (when possible) along drug groups. } \\
\text { Established in pre-clinical and clinical trials, and post-commercialization studies. } \\
\text { Regarded as part of drug PD (actions and effects, therapeutic and toxic effects). }\end{array}$ \\
\hline Adverse effects & $\begin{array}{l}\text { Described along drug properties } \\
\text { Therapeutic and adverse effects (modern sense) were all } \\
\text { regarded as properties of drugs. } \\
\text { Based on empirical use. }\end{array}$ & $\begin{array}{l}\text { Described in details along drug groups. } \\
\text { Established in pre-clinical and clinical trials, and post-commercialization studies. } \\
\text { Regarded as part of drug toxicology. } \\
\text { Addresses use in congestive heart failure, kidney failure, and liver failure. }\end{array}$ \\
\hline Toxicology & $\begin{array}{l}\text { Described along drug properties. } \\
\text { Governed by the Paracelsus adage "the dose makes the poison". } \\
\text { Based on empirical use. }\end{array}$ & $\begin{array}{l}\text { Encompasses adverse effects, acute, subacute and chronic toxicity, and treat- } \\
\text { ment of intoxications. } \\
\text { Addresses drug-drug interaction, contraindications, use in special populations } \\
\text { (children, elders, and pregnant women), and genotoxicity. }\end{array}$ \\
\hline
\end{tabular}

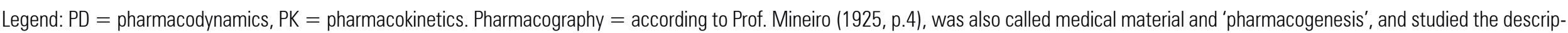
tion of drugs supplied by the three kingdoms of nature. Source: Table elaborated by the authors with data extracted from Mineiro (1925, 1926) and Silva (2010). 


\section{Comparison of the first Brazilian Pharmacopeia with Mineiro's pharmacology book}

A present-day pharmacopeia, from ancient Greek pharmakopoiia (drug making), is an official compilation of quality standards and specifications for medicines used in a specific country or region. Sanitary and regulatory authorities assemble it within a certain periodicity. The pharmacopeias act by providing quality specifications for dosage forms and pharmaceutical excipients, thus rendering the precise action and regulatory control of drugs on the market $\frac{56}{}$.

Publications describing drug properties have been compiled since the beginning of history, many of them became famous. The term "pharmacopeia" first appeared in a publication dating back to 1561 in Basle (Switzerland). However, similar woks, with authority endorsement, and thus official, appeared in 1546 (Nuremberg, Germany). Further, the British Pharmacopeia, for instance, was first published in 186457. A modern pharmacopeia regarded as world reference is the United States Pharmacopeia (USP), first issued in 1820, and currently on the $41^{\text {st }}$ Edition (2018) ${ }^{58}$.

The Brazilian Pharmacopeia came in place in 1926, compelled by a great deal of effort of its author, the pharmacist Rodolfo Albino Dias da Silva ${ }^{59}, 60$. Before that, international references were adopted, including the Pharmacopea Geral para o Reino e Dominios de Portugal ("General Pharmacopeia for the Kingdom and Domains of Portugal", 1794) - even after the independence of Brazil in 1822, the Portuguese Pharmacopeia (Codigo Pharmaceutico Lusitano - "Lusitanian Pharmaceutical Codex", 1835), and the French Pharmacopeia (French Codex, or Codex Medicamentarius Gallicus), posterior to 1837. As stated in the first edition preface ${ }^{61}$ : - "Brazil could not continue to be governed, concerning the practice of pharmacy, by a foreign code, which, while great for its country, did not satisfy our needs at all". Hence, the first Brazilian Pharmacopeia, even following standards of developed countries, was remarkably unique, for it contained numerous endemic medicinal plants from Brazil - not described anywhere else ${ }^{62}$.

Concerning the general organization of the compendia, Curso de Pharmacologia 63,64 and the first Brazilian Pharmacopeia $a^{65}$ are remarkably similar. Both present a general section detailing introductory topics, followed by individual descriptions of the drugs (including properties, applications, dosage and toxicity), drug identification assays and identification of impurities, most common chemical reactions, dosage forms, storage, and incompatibilities.

Mineiro named his introductory section "Preliminaries", where he described definitions of pharmacology, physics, chemistry, natural history and physiology; differentiated foods, medicines, poisons, drugs, venom and viruses. Mineiro also stated that drugs were divided into simple (base and vehicle or excipient) and compounds (base, vehicle, adjuvants, correctives, and intermediates), and could be used in solid, semisolid, liquid and vapor forms. In addition, there were also postulates about the "art of formulating", which "teaches the rules of prescribing and administering medicines" The Brazilian Pharmacopoeia (1926), in contrast, had the introductory section called "Generalities", where information and standardization of concepts such as weights and measures, density, temperature, percentages, solubility, moisture, chemical reactions, assays and titrations, glasses, conservation of substances and maximum doses. The section "Generalities" was followed by the description of general tests and processes (determination of alcohol, determination of alkaline salts, sterilization and disinfection, examination of plant drugs, acidity, esterification, iodine, refraction and saponification indices; freezing, boiling and melting points, solubility, distillation and sublimation). The aspects analyzed in this comparison are further detailed in Table 2. 
Table 2: Comparison of Mineiro's Curso de Pharmacologia $(1925,1926)$ with Pharmacopeia dos Estados Unidos do Brasil $(1926)$

Aspects Pharmacopeia dos Estados Unidos do Brasil Curso de Pharmacologia

General part (generalities, general essays and processes). Monographs on

Overall organization plant and animal drugs, chemicals, and officinal preparations. Articles in alphabetical order.

\section{Plant drugs}

Plant drug nomenclature (scientific name of plant and family); part of the plant used; pharmacognostic characterization; macroscopy and

Drug description microscopy; conservation; maximum doses; officinal employment; toxicity (when applicable).

\section{Chemical drugs}

Name, synonyms, and Latin name; raw and rational chemical formulas; atomic weight; conservation; maximum doses; officinal employment; toxicity (when applicable).
Introductory topics (preliminary). Drug by drug description (without formal divisions). Articles assorted by alphabetical order into chemical groups.
Dosing; identification essay; falsifications and impurities essay;

Essays characterization (physical and organoleptic characteristics: appearance, crystallization forms, color, smell, taste, solubility, melting point, and characteristic reactions).

\section{Plant drugs}

Name and synonyms; formula (not all); preparation; properties (applications); dosage; formulations and dosage forms.

\section{Chemical drugs}

Name and synonyms; formula (not all); preparation (industrial and laboratorial processes); properties (applications); dosage; formulations and dosage forms. 
We truly deem Mineiro's compendium an authentic pharmacology book, which encompasses technical approaches besides pharmacology itself. It was hypothesized that Mineiro attempted to fulfill the lack of regulatory guidelines, namely a national pharmacopeia, by encompassing in his lessons concepts of drug quality control and pharmaceutics. Therefore, Curso de Pharmacologia focused much more on drug formulation and dosage forms, than on properties of the active ingredients themselves. At the beginning of the twentieth century, pharmacology was not yet fully addressed independently of "medical matter" (description and collection of drugs) and the "art of formulating", since they were intrinsically related and there were no industrialized drugs at the time. The pharmaceutical industry introduced then large-scale manufacturing models of drugs and medical products, and magisterial preparations gave way to fully industrialized drugs ${ }^{67}, 68$. A detailed description of the "art of formulating" became less necessary, and intensive research in the fields of physiology and pharmacology produced enough knowledge to fill entire pharmacology books (i.e. Goodman and Gilman's The Pharmacological Basis of Therapeutics, first issued in 194169).

\section{Brazilian pharmacology textbooks employed in higher education curricula}

The analysis of the discipline programs official reference lists showed the most prevalent Brazilian authors used to teach pharmacology in Brazil. Two well-known and largely used Brazilian pharmacology textbooks are the aforementioned Farmacologia, by Penildon Silva, and Farmacologia Clínica e Terapêutica ${ }^{70,71}$ ("Clinical Pharmacology and Therapeutics" - first edition in 1992, and most recently in 2017) by Flávio Danni Fuchs and Lenita Wannmacher. Academic degree programs of Pharmacy, Medicine, Nursing, Nutrition, Biological Sciences, Physical Education, and Phonoaudiology currently adopt such textbooks along with well-established U.S. book references, mainly Goodman and Gilman's The Pharmacological Basis of Therapeutics ${ }^{72}$. Bittencourt, Caponi, and Maluf $\underline{-33}$ proposed a similar study in 2013, to analyze all editions of Goodman and Gilman's describing how pharmacology as a science was presented to students and practitioners throughout various editions of a textbook with world projection. Another pharmacology textbook written by a Brazilian author listed is Farmacologia Integrada ${ }^{74}$ ("Integrated Pharmacology"), organized by Roberto DeLucia (latest edition in 2014), being the third one more used.

Some other references comprise Brazilian pharmacology books. Despite the risk of being outdated, apparently such traditional books are useful didactic material for pharmacology teaching. Examples of the aforementioned books include Farmacologia Prática sem Aparelhagem ${ }^{75}$ by Elisaldo Luiz de Araújo Carlini (1978), Farmacologia Aplicada ${ }^{76}$ by Antonio Carlos Zanini and Seizi Oga (5 $5^{\text {th }}$ Edition, 1994), and Manual de Farmacologia Clínica, Terapêutica e Toxicologia ${ }^{77}$ by Darci Roberto Lima (2004). Some other references of pharmacology textbooks by Brazilian authors with minor projection are showed in Part 3 of the supplementary material.

Concerning these data, we can assume that pharmacology books published by Brazilian authors have a huge contribution to health professionalization, even though we consider pharmacology book content approach as the initial competency formation ${ }^{78}$.

\section{Conclusion}

Mineiro pioneered compiling a pharmacology compendium in early-twentieth century, intended to be a guide for Brazilian pharmacy students. Penildon envisioned the edition of a major volume of general pharmacology, issued in 1980. One hundred years after Mineiro, Penildon's book became the state-of-the-art Brazilian pharmacology reference.

It is sensible to consider, from the comparison of Mineiro's and Penildon's books that not only breakthrough drugs have been obtained, but also the perception of pharmacology evolved throughout the twentieth century. The emphasis given on drug formulation and dosage forms are no longer described in pharmacology books. Topics related to patient 
safety became a major preoccupation, and drug toxicity and side effects are now compulsorily depicted in detail on pharmacology textbooks. Moreover, pharmacology evolved, and as we could see from the comparison of Curso de Pharmacologia with the first Brazilian Pharmacopeia, Mineiro's book resembles much more the latter than a modern pharmacology textbook. Therefore, our hypothesis that Mineiro attempted to fulfill the lack of an official pharmaceutical

code, namely a Brazilian Pharmacopeia, while conceiving his works is still valid.

\section{Notes and references}

Weilher Paulo dos Santos holds a bachelor's degree in Pharmacy and a master's degree in Pharmaceutical Sciences by the Pharmaceutical Sciences Graduate Program (CiPharma) of UFOP. E-mail: weilher.santos@aluno.ufop.edu.br

Andrea Grabe-Guimarães is a full professor at the Pharmacy department of the School of Pharmacy of UFOP. E-mail: grabe@ufop.edu.br

* $\quad$ The authors would like to thank Ms. Ingrid Borges (MPh/UFOP Museologist) for her assistance, Mr. Igor Lacerda Guimarães (FAPEMIG grantee), Mr. Gabriel José Lucas Moreira (UFOP's extension project grantee), and the Pharmaceutical Sciences Graduate Program (CiPharma) of UFOP for all the support. Funding to this project was provided by FAPEMIG (project APQ-02733-15) and CAPES (grant). We also thank to Mrs. Nancy Scardua Binda and Mr. Victor Viera de Godoy for the ideas contribution.

1 DIAS, José Ramos. Apontamentos históricos do sesquicentenário da Escola de Farmácia de Ouro Preto. Ouro Preto: UFOP/Escola de Farmácia, 1989.

2 VELLOSO, Verônica Pimenta; MADUREIRA (red.); Francisco José Chaga (rev.). Escola de Farmácia de Ouro Preto. Dicionário Histórico-Biográfico das Ciências da Saúde no Brasil (1832-1930). Rio de Janeiro: Casa de Oswaldo Cruz/Fiocruz. Available at: http://www.dichistoriasaude.coc.fiocruz.br/iah/pt/ verbetes/escfarop.htm. Accessed in: July 152017.

3 DIAS, 1989, op. cit.

4 VELLOSO; MADUREIRA, 2017, op. cit.

5 GOMES, Bernadino Antonio. Elementos de Pharmacologia Geral ou Principios Geraes de Materia Medica e de Therapeutica. 3. ed. Lisboa: Typographia da Academia, 1873.

6 GUBLER, A. Leçons de Thérapeutique. 2. ed. Paris: V. Adrien Delahaye et C'ie, 1880. Place de l'École-de-Médecine.

7 RABUTEAU, A. Traité Élémentaire de Thérapeutique et de Pharmacologie. 4. ed. Paris: Adrien Delahaye et Émile Lecrosnier, 1884.

8 BRUNTON, T. Lauder. Traité de Pharmacologie, de Thérapeutique et de Matière Médicale. Ouvrage Traduit de l'Anglais sur la 3ie Édition. 3. ed. Bruxelas: A. Manceaux, 1888.

9 HAYEM, Georges. Leçons de Thérapeutique. Paris: G. Masson, 1891. (3). Libraire de l'Académie de Médecine.

10 MINEIRO, Jovelino. Curso de Pharmacologia. 2. ed. Belo Horizonte: Imprensa Official, 1925. 469 p. Vol. 1.

11 VALLE, José Ribeiro do. A Farmacologia no Brasil: Antecedentes e Perspectivas. São Paulo: Academia de Ciências do Estado de São Paulo (ACIESP), 1978.228 p.

12 DIAS, 1989, op. cit.

13 VELLOSO; MADUREIRA, 2017, op. cit.

14 MINEIRO, Jovelino. Curso de Pharmacologia. Ouro Preto: Tipografia Machado, 1911.

15 MINEIRO, 1925, op. cit.

16 MINEIRO, Jovelino. Curso de Pharmacologia. 2. ed. Belo Horizonte: Imprensa Official, 1926. 680 p. Vol. 2.

17 MINEIRO, 1925, op. cit.

18 VALLE, 1978, op. cit.

19 MINEIRO, 1925, op. cit.

20 MINEIRO, 1926, op. cit.

21 SILVA, Penildon. Farmacologia. 8. ed. Rio de Janeiro: Guanabara Koogan, 2010. 1384 p.

22 VALLE, 1978, op. cit.

23 Pan American Health Organization (PAHO). Lançamento da 5 a edição da Farmacopéia Brasileira. Medicamentos e Tecnologia em Saúde. Brasilia (DF): World Health Organization (WHO). 2010. Available at: https://www.paho.org/bra/index.php?option=com_content\&view=articlegid=1770:lancamento-da-5aedicao-da-farmacopeia-brasileirafltemid =838. Accessed in May 28, 2018.

24 SILVA, Rodolfo Alberto Dias da. Pharmacopeia dos Estados Unidos do Brasil. Codigo Farmaceutico Brasileiro. 1. ed. Rio de Janeiro: Companhia Editora Nacional, 1926. Available at: http://portal.anvisa.gov.br/documents/33832/261726/1_edicao.pdf/fef00ec7-a9b3-4fdd-a42d-60f0573b433b.

25 RUBIN, Ronald P. A brief history of great discoveries in pharmacology: in celebration of the centennial anniversary of the founding of the American Society of Pharmacology and Experimental Therapeutics. Pharmacological Reviews, v.59, n.4, p.289-359. 2007.

26 MINEIRO, 1925, op. cit.

27 MINEIRO, 1926, op. cit. 
MINEIRO, 1925, op. cit. MINEIRO, 1926, op. cit. SILVA, 2010, op. cit. MINEIRO, 1925, op. cit. MINEIRO, 1926, op. cit. SILVA, 1926, op. cit. VALLE, 1978, op. cit. SILVA, 1926, op. cit. VALLE, 1978, op. cit. PAHO, 2010, op. cit. VALLE, 1978, op. cit.

SANTOS, Ezequiel Correia dos. Monografia do Geissospermum vellosii vulgo Pau Pereira. Tese apresentada à faculdade de Medicina do Rio de Janeiro em 1848. Revista Flora Medicinal, v.15, n.8, p.315-339. 1948.

VALLE, 1978, op. cit. MINEIRO, 1925, op. cit. MINEIRO, 1926, op. cit. JONES, Alan Wayne. Early drug discovery and the rise of pharmaceutical chemistry. Drug Testing and Analysis, v.3, n.6, p.337-344. 2011. ATKINSON, Arthur J. (Jr). Individualization of drug therapy: an historical perspective. Translational and Clinical Pharmacology, v.22, n.2, p.52-54. 2014. International Union of Basic and Clinical Pharmacology (IUPhar). Introduction. Basle: International Union of Basic and Clinical Pharmacology. Available at: https://iuphar.org/about/introduction/. Accessed in June 20, 2018.

Sociedade Brasileira de Farmacologia e Terapêutica Experimental (SBFTE). Ata de Fundação. São Paulo: Sociedade Brasileira de Farmacologia e Terapêutica Experimental. 2017. Available at: http://www.sbfte.org.br/ata-de-fundacao/. Accessed in: June 202018.

RUBIN, 2007, op. cit.

JONES, 2011, op. cit.

World Health Organization (WHO). World Alliance for Patient Safety: forward programme 2005. Geneva: World Health Organization; 2004. 33 p. Available at: http://www.who.int/patientsafety/en/brochure final.pdf. Accessed in June 20, 2018.

SILVA, 2010, op. cit.

FAGIN, Dan. Toxicology: the learning curve. Nature, v.490, p.462-465. 2012.

GRANDJEAN, Philippe. Paracelsus revisited: the dose concept in a complex world. Basic \& Clinical Pharmacology \& Toxicology, v.119, n.2, p.126-132. 2016.

MINEIRO, 1925, op. cit.

MINEIRO, 1926, op. cit.

SILVA, 2010, op. cit.

World Health Organization (WHO). Review of world pharmacopoeias. InternationalMeeting of World Pharmacopoeias 2012. Geneva: World Health Organization; 2013. 20 p. Available at: http://www.who.int/medicines/areas/quality_safety/quality_assurance/resources/InternationalMeetingWorldPharmacopoeias_ QAS13-512Rev1_25032013.pdf. Accessed in May 28, 2018.

5 DUNLOP, Derrick Melville; DENSTON, T. C. The history and development of the "British Pharmacopoeia". British Medical Journal, v.2, n.5107, p.1250-1252. 1958.

The United States Pharmacopeial Convention (USP). USP timeline. Rockville: The United States Pharmacopeial Convention. 2018. Available at: http://www. usp.org/about/usp-timeline. Accessed in May 28, 2018.

SILVA, 1926, op. cit.

VALLE, 1978, op. cit.

SILVA, 1926, op. cit., preface (quotation).

PAHO, 2010, op. cit.

MINEIRO, 1925, op. cit.

MINEIRO, 1926, op. cit.

SILVA, 1926, op. cit.

MINEIRO, 1925, op. cit., p. 7

PEARSON, Glen J. Evolution in the practice of pharmacy — not a revolution! Canadian Medical Association Journal, v. 176, n. 9, p.1295-1296. 2007.

PEREIRA, Mariana Linhares; NASCIMENTO, Mariana Martins Gonzaga do. Das boticas aos cuidados farmacêuticos: perspectivas do profissional farmacêutico. Revista Brasileira de Farmácia (RBF), v. 92, n. 4, p.245-252. 2011.

GOODMAN, Louis S.; GILMAN, Alfred. As Bases Farmacológicas da Terapêutica: Compêndio de Farmacologia, Toxicologia e Terapêutica para Médicos e Estudantes. Tradução de Benjamin Gaspar Gomes. Rio de Janeiro: Guanabara Waissman Koogan LTDA, 1945.

FUCHS, Flávio Danni; WANNMACHER, Lenita. Farmacologia Clínica: Fundamentos da Terapêutica Racional. Rio de Janeiro: Guanabara Koogan, 1992.691 p. FUCHS, Flávio Danni; WANNMACHER, Lenita. Farmacologia Clínica e Terapêutica. 5. ed. Rio de Janeiro: Guanabara Koogan, 2017. 852 p.

BRUNTON, Laurence (ed.), CHABNER, Bruce A., KNOLLMAN, Bjorn (associated ed.). Goodman and Gilman's: the pharmacological basis of therapeutics. 
12. ed. New York: McGraw-Hill Education, 2011. 1808 p

73 BITTENCOURT, Silvia Cardoso; CAPONI, Sandra; MALUF, Sônia. Farmacologia no século XX: a ciência dos medicamentos a partir da análise do livro de Goodman e Gilman. História, Ciências, Saúde - Manguinhos, v.20, n.2, p.499-519. 2013.

74 DELUCIA, Roberto (org); PLANETA, Cleópatra da Silva; GALLACCI, Márcia; AVELLAR, Maria Christina W. de; FILHO, Ricardo Martins de Oliveira (co-authors). Farmacologia integrada: uso racional de medicamentos. 5. ed. São Paulo: Clube de Autores. 2014. 2 volumes.

75 CARLINI, Elisaldo Luiz de Araújo. Farmacologia Prática sem Aparelhagem. São Paulo: Sarvier, 1973. 198 p.

76 ZANINI, Antonio Carlos; OGA, Seizi. Farmacologia Aplicada. 5. ed. Rio de Janeiro: Atheneu, 1994. 739 p.

77 LIMA, Darci Roberto. Manual de Farmacologia. Clínica, Terapêutica e Toxicologia. Rio de Janeiro: Medsi, 2004. 3 volumes.

78 Ministério da Educação (MEC, Brazil). Resolução nº. 6 de 19 de outubro de 2017. Institui as diretrizes curriculares nacionais do curso de graduação em farmácia e dá outras providências. CNE/CES. Diário Oficial da União; Brasília (DF), Seção 1, p. 30.20 out 2017.

[Artigo recebido em Junho de 2019. Aceito para publicação em Setembro de 2019] 